\title{
Comparison of hydroxychloroquine plus moxifloxacin versus hydroxychloroquine alone on corrected QT interval prolongation in COVID-19 patients
}

\author{
Veysel Yavuza, Ferhat Ozyurtlua ${ }^{b}$, Nurullah Cetin ${ }^{c}$ \\ a Department of Cardiology, Akhisar Mustafa Kirazoglu State Hospital, Manisa, Turkey \\ ${ }^{b}$ Department of Cardiology, Grandmedical Hospital, Manisa, Turkey \\ ' Department of Cardiology, Celal Bayar University, Manisa, Turkey
}

ARTICLE INFO

Article history:

Submitted: 22. 3. 2021

Revised: 15. 4. 2021

Accepted: 17. 4. 2021

Available online: 4. 10. 2021

\section{Klíčová slova:}

Hydroxychlorochin

Korigovaný interval QT

Moxifloxacin

\section{SOUHRN}

Kontext: Hydroxychlorochin (HCQ) samotný nebo v kombinaci s některými antibiotiky či antivirotiky se podává v dosud neschválené indikaci při léčbě onemocnění COVID-19. Zdá se, že nejzávažnějším problémem z hlediska bezpečnosti těchto léčiv jsou jejich nežádoucí účinky na srdce. I když jsou k dispozici údaje o arytmogenních přihodách spojených s podáváním samotného HCQ, jako jsou prodloužení korigovaného intervalu QT (corrected QT, QTc), vznik torsade de pointes (TdP) nebo bradykardie, nemáme zatím dostatek údajů o účincích jeho kombinace s moxifloxacinem (MOX).

Cíl: Cílem naší studie bylo analyzovat účinky podávání HCQ samotného nebo v kombinaci s MOX, na interval QT, srdeční frekvenci a arytmické př́hody u pacientů s diagnózou COVID-19.

Metody: Naše studie byla monocentrická, kohortová, s pacienty hospitalizovanými mimo jednotku intenzivní péče a s klinickými známkami odpovídajícími pneumonii a s alespoň jedním pozitivním výsledkem vyšetření (metodou PCR z nazofaryngeálního stěru) na onemocnění COVID-19. Měřili jsme vstupní hodnoty intervalu QT a srdeční frekvence pacientů, jimž byl podáván bud' samotný HCQ, nebo kombinace HCQ plus MOX, a následně je srovnali s hodnotami po léčbě.

Výsledky: Do studie bylo zařazeno 312 pacientů (medián věku 42 [IQR 31,25-57,75] let; 54,16 \% mužů). Pacienti byli rozděleni do dvou skupin podle výše uvedené léčebné strategie následovně: samotný HCQ (166; $53,20 \%)$ nebo HCQ + MOX (146; 46,79 \%). Ve srovnání se vstupní hodnotou bylo u všech pacientů zaznamenáno statisticky významné prodloužení intervalu QTc po léčbě $(406,00[388,00-422,00]$ ms versus 418,00 $[401,00-435,00] \mathrm{ms} ; p<0,001)$. Porovnání vstupních hodnot intervalu QTc neprokázalo žádný statisticky významný rozdíl mezi skupinami se samotným HCQ a s kombinací HCQ + MOX $(403,00$ [384,50-419,00] ms versus 409,50 [390,00-425,00] ms; $p=0,086)$. Po léčbě se hodnoty QTc intervalu statisticky významně prodloužily ve skupině HCQ + MOX oproti skupině pacientů užívajících pouze samotný HCQ $(413,00$ [398,00-430,00] $\mathrm{ms}$ versus $426,50[405,00-441,00] \mathrm{ms} ; p<0,001)$. Po léčbě došlo u obou skupin ke statisticky významnému zpomalení srdeční frekvence, ze 79,00 $(70,00-88,00)$ tepů/min na $70,00(63,00-79,00)$ tepů/min ve skupině se samotným HCQ $(p<0,001)$ a z $80,00(70,00-88,00)$ tepů/min na $70,50(63,00-78,75)$ tepů/min ve skupině $s$ kombinací $\mathrm{HCQ}+\operatorname{MOX}(p<0,001)$. Na druhé straně nebyl nalezen statisticky významný rozdíl mezi skupinami z hlediska hodnot srdeční frekvence před léčbou a po ní.

Závěr: $V$ této kohortové studii bylo u pacientů s podáním HCQ pro léčbu onemocnění COVID-19 př́tomno vysoké riziko prodloužení intervalu QTc; souběžné podávání MOX a HCQ bylo spojeno s většími změnami v intervalu QTc. Během léčby nicméně nedošlo u žádného z pacientů ke vzniku maligní komorové arytmie ani k žádnému úmrtí. Při zvažování podávání HCQ, zvláště v kombinaci s MOX, musejí lékaři v klinické praxi pečlivě zvážit rizika a př́nosy při důsledném monitorování intervalu QTc. Je třeba provést další prospektivní studie, které by upřesnily vliv podávání uvedených léčiv na vznik arytmií u pacientů s onemocněním COVID-19.

(c) 2021, ČKS.

\section{ABSTRACT}

Background: Hydroxychloroquine (HCQ) alone or with some antibiotic and antiviral agents is used off label in the treatment of Coronavirus Disease 2019 (COVID-19). It seems that the most important safety problem about these medications are their cardiac side effects. Although there are data on arrhythmogenic events associated with the use of HCQ alone, such as corrected QT (QTC) prolongation, Torsade de pointes (TdP) or bradycardia, there are insufficient data on its combination with moxifloxacin (MOX).

Address: Ass. prof. Nurullah Çetin, MD, Department of Cardiology, Medical Faculty, Celal Bayar University, Uncubozköy Mahallesi Mimarsinan Sokak No: 189 - Yunusemre / Manisa, 45030 Turkey, e-mail: nurullah.cetin@cbu.edu.tr DOI: $10.33678 /$ cor.2021.053 
Objective: The aim of our study is to analyze the effect of HCQ alone or in combination with the use of MOX on QTc interval, heart rate, and arrhythmic events in patients with a diagnosis of COVID-19.

Methods: This is a single center cohort study of non-intensive care unit (ICU) patients hospitalized with clinical signs consistent with pneumonia and at least one positive COVID-19 nasopharyngeal polymerase chain reaction test result. QTc intervals and heart rates in patients whose treatment consisted of HCQ alone or its separate combination with MOX at baseline and post-treatment were calculated and compared.

Results: 312 patients were included (median age of 42 [IQR: 31.25-57.75] years, 54.16\% male). Patients were divided into two groups based on their in-hospital treatment strategy as follows: HCQ alone ( $\mathrm{n}: 166$, $53.20 \%$ ) or HCQ + MOX (n: 146, 46.79\%). As compared to baseline, QTc intervals were significantly increased in all patients after treatment (406.00 [388.00-422.00] ms vs 418.00 [401.00-435.00] ms, $p<0.001)$. When the baseline QTc intervals were evaluated, there was no statistically significant difference between HCQ alone and HCQ + MOX groups (403.00 [384.50-419.00] ms vs. 409.50 [390.00-425.00] ms, p: 0.086). After treatment period, QTc intervals were significantly higher in HCQ + MOX group compared to the group in which patients only used HCQ (413.00 [398.00-430.00] ms vs. 426.50 [405.00-441.00] ms, $p<0.001)$. We found a significant decrease in heart rate in both groups after treatment period. From 79.00 (70.00-88.00) bpm to 70.00 (63.00-79.00) bpm in HCQ alone group ( $p<0.001)$ and from $80.00(70.00-88.00)$ bpm to $70.50(63.00-78.75)$ bpm in HCQ + MOX group $(p<0.001)$. On the other hand, no statistically significant difference was observed between the groups in terms of heart rates either before or after the treatment.

Conclusion: In this cohort study, patients who received HCQ for the treatment of COVID-19 were at high risk of QTc prolongation, and concurrent treatment with MOX was associated with greater changes in QTc.

Keywords:

Corrected QT interval However, none of patients experienced malignant ventricular arrhythmia or death during treatment. Clinicians should carefully weigh risks and benefits with close monitoring of QTC if considering treatment with Hydroxychloroquine HCQ especially concomitant use with MOX. Further prospective studies are needed to determine the exact Moxifloxacin implications of these drugs on arrhythmias in patients with COVID-19.

\section{Introduction}

A number of undetermined pneumonia cases were reported on December 31st 2019 in the city of Wuhan in the state of Hubei of China. ${ }^{1}$ After a short period of time, Centers for Disease Control and Prevention in China insulated a new coronavirus as the active ingredient of this pandemic which was referred to as severe acute respiratory distress syndrome coronavirus 2 (SARS-CoV-2) in the epithelial cells of humans. ${ }^{2}$ On February 12th 2020, World Health Organization (WHO) referred the disease caused by SARS-CoV-2 as Coronavirus Disease 2019 (COVID-19), and the disease was announced to be a pandemic on March 11th $2020 .^{3}$ Since that particular date, over 100 million people have become infected, and over a million people lost their lives due to the pandemic.

Although there is not a validated medication to prevent or treat the COVID-19 infection, it is reported that hydroxychloroquine (HCQ) which is an antimalarial medication alone or the combination of HCQ with other antibiotic and antiviral medications may have a positive effect on the clinic results and the viral load of the infected patients. ${ }^{4}$ The obtained results have led to the common use of this treatment regimen in COVID-19 treatment across the world. Furthermore, the research on vaccination and appropriate medical treatment are still continuing. It is known that HCQ can cause fatal arrhythmia by prolonging the QT interval in electrocardiography (ECG). However, there are data stating that this situation is a dosage-related situation. ${ }^{5}$

Since some of the patients who were admitted with the initial diagnosis of COVID-19 infection cannot be diagnosed with atypical pneumonia determiner, these patients receive atypical pneumonia treatment along with COVID-19 treatment. As in the other viral infections, an- other significant morbidity and mortality reason in $\mathrm{CO}$ VID-19 patients is secondary bacterial infections. In the treatment guide of Ministry of Health of the Republic of Turkey, moxifloxacin (MOX), which is among the fluoroquinolone type antibiotics, is among the treatment options for this patient group. Similar to HCQ, MOX prolongs QT interval and has fatal side effect potentials. ${ }^{6}$

In the current study, it is aimed to research the effect of HCQ alone and its combination with MOX on the prolonging of QT interval in the patients with COVID-19.

\section{Methods}

The current study is a retrospective observational study examining the patients admitted with COVID-19 diagnosis and receiving their medical treatments in accordance with the COVID-19 algorithm of the Ministry of Health of the Republic of Turkey (MHRT). ${ }^{7}$ Inclusion criteria were as follows: 1) patients diagnosed with COVID-19 by polymerase chain reaction (PCR) test (SARS-CoV-2, qPCR Detection Kit by Bio-Speedy); 2) patients $>18$ years and were followed in in-patient ward; 3) patients who were in sinus rhythm; 4) patients whose ECG was taken before starting treatment and after the treatment period. According to the hospital protocol formed in the light of treatment recommendations of MHRT COVID-19 potential diagnosed patient and data in the literature in the process in which the included patients were treated, on the first day, the patients received $400 \mathrm{mg} \mathrm{HCQ} \mathrm{p.o.} \mathrm{twice} \mathrm{a} \mathrm{day} \mathrm{as} \mathrm{their}$ load dosage, and on the subsequent days, the patients received $200 \mathrm{mg} \mathrm{HCQ}$ p.o. twice a day as their five-day treatment. The intravenous MOX $500 \mathrm{mg}$ once a day was administered for five days to the patients with suspicion of atypical pneumonia and/or secondary infection findings. The treatment regimen was administered 
by caring physicians in accordance with clinical and laboratory findings of patients. Blood calcium, magnesium and potassium levels of the patients were measured daily and electrolyte replacement was performed in patients with electrolyte imbalance.

Exclusion criteria were; patients with QRS width $\geq 120$ ms before treatment, any bundle branch block, pre-excitation syndromes, patients with an implantable cardioverter-defibrillator or cardiac resynchronization therapy, patients with a cardiac pacemaker, patients who had a rhythm other than sinus one, pregnant women, patients who have to use other drugs (antipsychotics, antidepressants, antiarrhythmics, other antimicrobials etc.) that may cause QTc prolongation and patients with chronic kidney failure (estimated glomerular filtration rate $<60$ $\mathrm{ml} / \mathrm{min} / 1,73 \mathrm{~m}^{2}$ according to the Cockcroft-Gault formula).

All patients included in the study had 12-lead ECG recorded at $50 \mathrm{~mm} / \mathrm{sec}$ (Nihon Kohden EKG 1250). Baseline ECGs were obtained prior to medication initiation and control ECGs were obtained after medication completed on the fifth day. Electrocardiographic analysis included heart rhythm and rate, P-QRS-T intervals duration, atrioventricular and intraventricular conduction disturbances in all ECGs. All QT intervals obtained from an ECG were manually measured from the onset of the first deflection of QRS complex to the end of T wave on ECG papers. The end of the T wave was determined by the tangent method. QT measurement was performed according to guideline proposed by expert panel. ${ }^{8}$ Leads $\mathrm{II}, \mathrm{V}_{5}$ or $\mathrm{V}_{6}$ were utilized for the measurement of the QT interval on ECG. Measured longest QT interval was used. Two cardiologists blind to the patient data performed ECG measurements of QT intervals. In case of problems with measurement and if discrepancy between these two cardiologists was more than $5 \%$, the third cardiologist was invited to resolve the problem. QT corrections were performed using the Bazett method on the patients' initial ECG and posttreatment ECG. Since the Bazett method overestimated the QTc interval, the Framingham method was used for measurement in patients with a heart rate of 100 and above.

Also, age, gender, body mass index (BMI), co-morbid situations, creatinine, aspartate aminotransferase (AST) , alanine aminotransferase (ALT) and CRP which are laboratory values, angiotensin-converting enzyme inhibitors (ACE-I) and angiotensin receptor blocker (ARB) group antihypertensive medication use and prognosis situations of the patients were recorded. The patients with incomplete data in their folders were called and the data were completed. For the current study, MHRT COVID-19 Scientific Research Assessment Commission approval and Manisa Celal Bayar University Ethical Committee (Manisa, Turkey) approval were taken.

Statistical analysis was performed using IBM SPSS Statistics 26, and figures were constructed by using GraphPad Prism 8. Categorical variables were summarized with the use of frequencies and proportions and were compared with the use of the Pearson's chi-square test or Fisher's exact test in cases where applicability conditions were not met. Continuous variables were summarized as median and interquartile range (IQR). The Shapiro-Wilk test was used to check whether the continuous variables were distributed normally. The ECG characteristics (QTC interval and $\mathrm{HR}$ ) of patients before vs. after treatment period were compared using Wilcoxon signed rank test. The Mann-Whitney $U$ test evaluated whether there was a significant difference between groups in terms of ECG characteristics. In all analyses, $p<0.05$ was taken to indicate statistical significance.

\section{Results}

\section{Patient demographics and characteristics}

Three hundred and twelve non-ICU hospitalized COVID-19 patients were retrospectively analyzed and included in this study. The study sample consisted of $54.16 \%$ males with a median age of 42 (IQR: 31.25-57.75) years. Patients were treated with $\mathrm{HCQ}$ alone or $\mathrm{HCQ}+\mathrm{MOX}$ combination during five days. The median length of follow-up was six (6-14) days. Clinical characteristics of all population are presented in Table 1.The prevalence of medical comorbidities was substantial, as $11.84 \%$ of patients had a history of hypertension, $12.17 \%$ had a history of diabetes mellitus, $4.93 \%$ had a history of coronary artery disease, $0.32 \%$ had a history of heart failure, and $10.52 \%$ had a history of chronic obstructive pulmonary disease. Additionally, $20.72 \%$ of patients smoked. The median BMI of the patients was $26.40(23.87-29.30) \mathrm{kg} /$ $\mathrm{m}^{2}$. Laboratory tests of the study population are reported in Table 1. Seven patients (3.0\%) died during their hospital stay due to pulmonary failure without evidence of ventricular arrhythmias.

Patients were divided into two groups based on their in-hospital treatment strategy as follows: $\mathrm{HCQ}$ alone (n: $166,53.20 \%$ ) or HCQ + MOX (n: 146, 46.79\%). The demographic findings, comorbidities, and laboratory tests of the study groups are shown in Table 1. Patients who received HCQ + MOX were significantly older (39.50 [29.25-52.75] years vs. 48.00 [35.00-64.00] years, $p<$ 0.001 ) and they also had significantly higher CRP levels than patients who received only HCQ $(0.42[0.18-1.51]$ $\mathrm{mg} / \mathrm{dl}$ vs. $1.26[0.34-3.44] \mathrm{mg} / \mathrm{dl}, \mathrm{p}<0.001)$. There were no significant differences in terms of comorbidities including hypertension, diabetes mellitus, coronary artery disease, heart failure, chronic obstructive pulmonary disease and smoking between the two groups. Serum creatinine, potassium, aspartate aminotransferase, alanine aminotransferase, white blood cell and hemoglobin levels were also similar between $\mathrm{HCQ}$ and $\mathrm{HCQ}+\mathrm{MOX}$ groups.

\section{Electrocardiographic characteristics}

All patients had a baseline ECG before starting treatment and a repeat ECG after the five-day treatment. Individual QTc intervals of all patients and treatment groups before and after treatment are shown in Figure 1. As compared to baseline, QTc intervals were significantly increased in all patients after treatment $(406.00$ [388.00-422.00] ms vs 418.00 [401.00-435.00] ms, $p<0.001$ ). It was found that there was a significant prolongation in QTc intervals after treatment compared to before treatment in the group that receives both $\mathrm{HCQ}$ alone and $\mathrm{HCQ}$ plus MOX. In the 


\begin{tabular}{|c|c|c|c|c|}
\hline & Overall & HCQ alone & HCQ + MOX & $p$-value \\
\hline $\mathrm{n}(\%)$ & 312 & $166(53.20 \%)$ & $146(46.79 \%)$ & \\
\hline Age, years & $42.00(31.25-57.75)$ & $39.50(29.25-52.75)$ & $48.00(35.00-64.00)$ & $<0.001$ \\
\hline Gender (male), n (\%) & $169(54.16 \%)$ & $89(53.61 \%)$ & $80(54.79 \%)$ & 0.835 \\
\hline BMI & $26.40(23.87-29.30)$ & $26.57(24.48-29.32)$ & $25.96(23.72-29.29)$ & 0.269 \\
\hline \multicolumn{5}{|l|}{ Comorbidities, n (\%) } \\
\hline HT & $36(11.84 \%)$ & $15(9.37 \%)$ & $21(14.58 \%)$ & 0.161 \\
\hline DM & $37(12.17 \%)$ & $15(9.37 \%)$ & $22(15.27 \%)$ & 0.116 \\
\hline CAD & $15(4.93 \%)$ & $6(3.75 \%)$ & $9(6.25 \%)$ & 0.315 \\
\hline $\mathrm{HF}$ & $1(0.32 \%)$ & $1(0.62 \%)$ & $0(0 \%)$ & 0.342 \\
\hline COPD & $32(10.52 \%)$ & $15(9.37 \%)$ & $17(11.80 \%)$ & 0.491 \\
\hline Smoking & $63(20.72 \%)$ & $40(25.00 \%)$ & $23(15.97 \%)$ & 0.053 \\
\hline \multicolumn{5}{|l|}{ Laboratory data } \\
\hline Creatinine, mg/dL & $0.75(0.62-0.87)$ & $0.73(0.62-0.84)$ & $0.77(0.62-0.88)$ & 0.127 \\
\hline Potassium, mEq/L & $4.11(3.92-4.40)$ & $4.12(3.95-4.40)$ & $4.10(3.90-4.40)$ & 0.489 \\
\hline AST, $\mu \mathrm{kat} / \mathrm{L}$ & $26(21-35)$ & $26(21-35)$ & $26(22-36)$ & 0.489 \\
\hline ALT, $\mu \mathrm{kat} / \mathrm{L}$ & $26(18-38)$ & $28(19-40)$ & $25(17-36)$ & 0.207 \\
\hline $\mathrm{WBC}, 10^{3} / \mu \mathrm{L}$ & $6.52(4.81-8.58)$ & $6.44(5.15-8.51)$ & $6.64(4.74-8.57)$ & 0.958 \\
\hline $\mathrm{Hg}, \mathrm{g} / \mathrm{dL}$ & $13.40(12.10-15.07)$ & $13.40(12.30-15.17)$ & $13.40(12.00-14.80)$ & 0.527 \\
\hline CRP, mg/dL & $0.71(0.24-2.13)$ & $0.42(0.18-1.51)$ & $1.26(0.34-3.44)$ & $<0.001$ \\
\hline Mortality & $7(3.00 \%)$ & $5(4.13 \%)$ & $2(1.78 \%)$ & 0.294 \\
\hline
\end{tabular}

ALT - alanine aminotransferase; AST - aspartate transaminase; BMI - body mass index; CAD - coronary artery disease; COPD - chronic obstructive pulmonary disease; CRP - C-reactive protein; DM - diabetes mellitus; HCQ - hydroxychloroquine; HF - heart failure; Hg - hemoglobin; HT - hypertension; MOX - moxifloxacin; WBC - white blood cell count.

\begin{tabular}{|c|c|c|c|c|c|c|}
\hline & \multicolumn{3}{|l|}{ QTc (ms) } & \multicolumn{3}{|l|}{ HR (bpm) } \\
\hline & Before & After & $p$-value & Before & After & $p$-value \\
\hline $\begin{array}{l}\text { Overall } \\
\text { (n: } 312)\end{array}$ & $406.00(388.00-422.00)$ & $418.00(401.00-435.00)$ & $<0.001$ & $79.00(70.00-88.00)$ & $70.00(63.00-79.00)$ & $<0.001$ \\
\hline $\begin{array}{l}\text { HCQ alone } \\
\text { (n: 166) }\end{array}$ & $403.00(384.50-419.00)$ & $413.00(398.00-430.00)$ & $<0.001$ & $80.00(70.00-88.00)$ & $70.50(63.00-78.75)$ & $<0.001$ \\
\hline $\begin{array}{l}\text { HCQ + MOX } \\
(n: 146)\end{array}$ & $409.50(390.00-425.00)$ & $426.50(405.00-441.00)$ & $<0.001$ & $79.00(70.00-89.25)$ & $70.00(63.00-81.00)$ & $<0.001$ \\
\hline
\end{tabular}

HCQ - hydroxychloroquine; HR - heart rate; MOX - moxifloxacin; QTC - corrected QT.

Table 3 - Comparison of electrocardiography parameters between groups

\begin{tabular}{|l|l|l|l|}
\hline & HCQ alone & HCQ + MOX & $p$-value \\
\hline & (n: 166$)$ & $(\mathrm{n:} \mathrm{146)}$ & \\
\hline $\begin{array}{l}\text { Before treatment } \\
\text { QTc (ms) }\end{array}$ & $403.00(384.50-419.00)$ & $409.50(390.00-425.00)$ & 0.086 \\
\hline $\begin{array}{l}\text { HR (bpm) } \\
\text { After treatment }\end{array}$ & $80.00(70.00-88.00)$ & $79.00(70.00-89.25)$ & 0.961 \\
\hline QTc (ms) & $413.00(398.00-430.00)$ & $426.50(405.00-441.00)$ & $<0.001$ \\
\hline HR (bpm) & $70.50(63.00-78.75)$ & $70.00(63.00-81.00)$ & 0.472 \\
\hline$\triangle$ QTc (ms) & $16.50(7.00-25.00)$ & $18.50(8.00-32.25)$ & 0.073 \\
\hline
\end{tabular}

HCQ - hydroxychloroquine; HR - heart rate; MOX - moxifloxacin; QTC - corrected QT. 

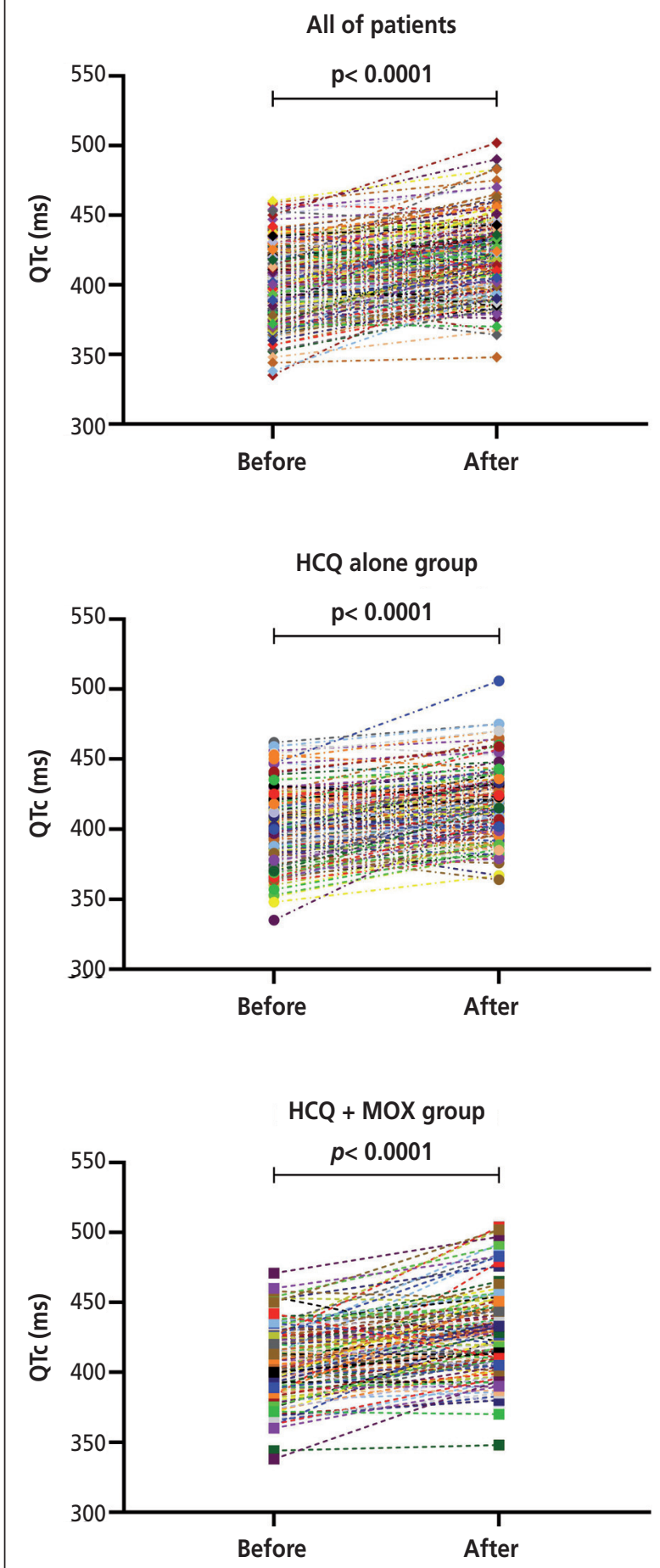

Fig. 1 - Individual QTc intervals of patients according to treatment groups before and after treatment. HCQ - hydroxychloroquine; MOX - moxifloxacin.

group that received HCQ alone, the median QTC interval was 403.00 (384.50-419.00) ms before treatment and 413.00 (398.00-430.00) ms after treatment ( $p<0.001)$. On the other hand, in HCQ + MOX group, the median QTC interval was 409.50 (390.00-425.00) ms before treatment and 426.50 (405.00-441.00) ms after treatment $(p<0.001)$ (Table 2).

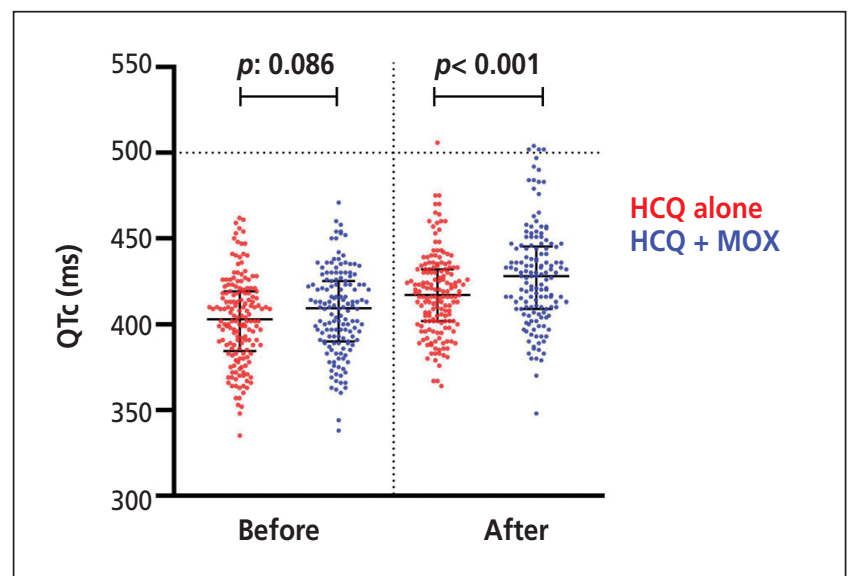

Fig. 2 - Comparison of pre- and post-treatment QT intervals between treatment groups. HCQ - hydroxychloroquine; MOX - moxifloxacin.

When the baseline QTc intervals were evaluated, there was no statistically significant difference between HCQ alone and HCQ + MOX groups (403.00 [384.50-419.00] ms vs. 409.50 [390.00-425.00] ms, p: 0.086) (Table 3). As demonstrated in Figure 2, after treatment period, QTc intervals were significantly higher in the HCQ + MOX group compared to the group in which patients only used HCQ (413.00 [398.00-430.00] ms vs. 426.50 [405.00-441.00] ms, $p<0.001)$. Although the post-treatment QTc intervals were significantly different between the groups, there was no significant difference between the $\Delta$ QTc (the difference between the QTc intervals before and after the treatment) values (16.50 [7.00-25.00] ms vs. 18.50 [8.00-32.25] ms, p: 0.073) (Table 3). QTc >500 ms, which is considered to be a significant prolongation of the QTc interval, was observed in one patient in HCQ alone group, and in four patients in the HCQ + MOX group after the treatment period. All of these patients were female, and the median age was 75 (53-83) years. Also, the median QTc interval was 447 (430-450) ms before treatment. It was significantly higher when compared with the patients whose QTc interval was below 500 ms after the treatment period. When compared with the patients who have a QTc interval of less than 500 ms, no significant difference was observed between the two groups in terms of comorbid conditions and laboratory parameters. Another parameter that indicated significant QTc interval prolongation, $\Delta$ QTc $>60$ ms was seen in one patient in the HCQ alone group and in seven patients in the HCQ + MOX group. There were no instances of ventricular tachycardia, ventricular fibrillation, or significant conduction delay during follow-up.

After the treatment period, we found a significant decrease in heart rate in both groups. From 79.00 (70.00$88.00) \mathrm{bpm}$ to $70.00(63.00-79.00) \mathrm{bpm}$ in HCQ alone group $(p<0.001)$ and from $80.00(70.00-88.00) \mathrm{bpm}$ to 70.50 (63.00-78.75) bpm in HCQ + MOX group $(p<0.001)$ (Table 2 and Fig. 3). However, none of the patients developed symptomatic bradycardia. On the other hand, no statistically significant difference was observed between the groups in terms of heart rates either before or after the treatment (Table 3 and Fig. 4). 

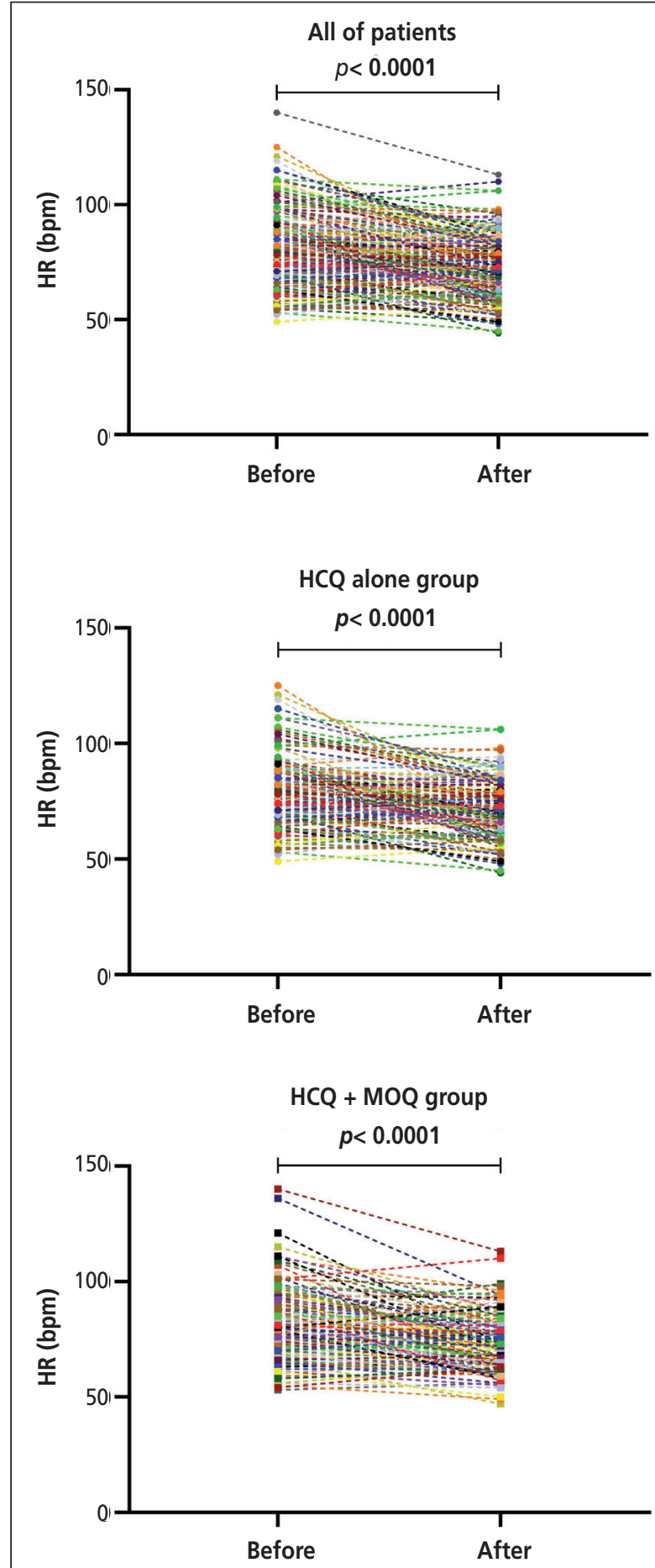

Fig. 3 - Individual HR of patients according to treatment groups before and after treatment. HCQ - hydroxychloroquine; HR - heart rate; MOX - moxifloxacin.

\section{Discussion}

In the current study, a significant prolonging in the QTC intervals of all the patients who were admitted to the hospital for their medical treatment for COVID-19 (non-ICU)

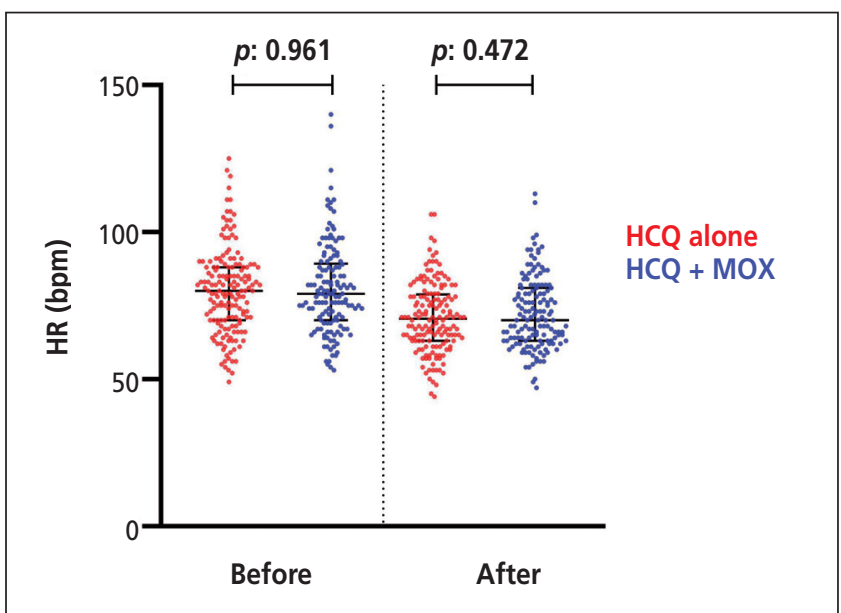

Fig. 4 - Comparison of pre- and post-treatment HR between treatment groups. HCQ - hydroxychloroquine; HR - heart rate; MOX moxifloxacin.

after their treatments according to their baseline values. Furthermore, a significant QTC prolongation compared to baseline levels was found in both treatment groups. When the two groups are compared, no significant difference was found between their pre-treatment baseline QTc values. After the treatment, QTc values of both HCQ combined with MOX group has a significant prolonging when compared with HCQ alone group. A decrease in heart rate was observed in both treatment groups after the treatment period. The decrease in heart rate of the patients who used HCQ alone and HCQ with MOX was found statistically significant.

The in vitro studies have shown that $\mathrm{HCQ}$, which has been used in the treatment of malaria and rheumatic diseases for many years, prevents the entrance of SARS-COV-2 and its replications. ${ }^{9}$ On the other hand, it is also emphasized that HCQ can play a role in bringing cytokine storm, which emerges in the late periods of the disease, under control with the immunomodulatory effect of it. HCQ, which was first used in China - the starting point of the pandemic - and then used in several countries with the studies supporting its effectiveness in the treatment of COVID-19, took its part as well in the treatment algorithm prepared by the Ministry of Health in Turkey..$^{10}$ In the light of adverse data related to $\mathrm{HCQ}$, some of the countries excluded the medication from their treatment algorithms. One of the greatest drawbacks of HCQ treatment is QT prolongation and the arrhythmic events related to this, and eventually, death. HCQ cause prolonged QT by inhibiting voltage-gated sodium and potassium channels, which can result in arrhythmia and sudden cardiac death. In a cohort study, which included 90 patients conducted by Mercuro et al., the risk of prolonged QT was, determined high in the patients who received HCQ because of COVID-19 related pneumonia and TdP was observed in only one patient. ${ }^{11}$ On the other hand, in another study in which 119 patients using HCQ were included, although TdP or arrhythmogenic deaths were not observed, it was found out that there was a significant prolonging in the QTc values during the treatment process. ${ }^{12}$

It was displayed in vitro that HCQ causes bradycardia by causing sinoatrial node inhibition through If channels. ${ }^{13}$ 
In a study on systemic lupus erythematosus (SLE) patients, it is revealed that the heart rate decreasing effect of HCQ was dosage dependent. The resting heart rate of the patients that receive high dosage was found $11 \%$ lower..$^{14}$ In the study conducted by Romani et al. in order to evaluate the cardiotoxic effects of HCQ use before COVID-19 and during the pandemic, while medication-related cardiomyopathy and conduction abnormalities were observed more frequently in the pre-pandemic period; pandemic period ventricular arrhythmia and sinus bradycardia were reported statistically more significantly when compared to pre-pandemic period. ${ }^{15}$ It is emphasized that in pre-COVID-19 period, chronic use of HCQ can cause high cumulative dose-dependent metabolic induced cardiac toxicity, and on the other hand, the close cardiac monitorization of COVID-19 patients in the light of guidelines can create this difference. Although the HCQ dose is low in our study, a significant decrease in the heart rate that is related to the medication was observed after the treatment.

In our center, mostly MOX was preferred for the patients in whom atypical pneumonia could not be ruled out and for the patients who are thought to have a secondary infection. MOX is an antibiotic of fluoroquinolone group, which inhibits bacterial type 2 topoisomerase activity and can cause QT segment prolonging just like other group members. MOX prolongs QT interval by blocking the rapid component of the delayed rectifier potassium current $(\mathrm{IKr})$ in the heart. ${ }^{16}$ Furthermore, in case there are risk factors such as long QT syndrome, female gender, old age, bradycardia, electrolyte disorders, cardiac disease history, liver and kidney disorders and comorbid QT prolonging medications in MOX use, the risk of prolonged QT and TdP increases. ${ }^{17}$ In a study where HCQ and MOX were combined in the treatment of COVID-19 pneumonia, the QTc values significantly increased on the fifth day of the treatment. ${ }^{18}$ However, it is hard to speculate if QT prolonging stems from HCQ or MOX since no comparison had been made with the group that used HCQ alone in that study. In our study, a significant QTc prolonging was observed in the patient group, which used HCQ and MOX combination when compared to the group of patients using HCQ alone. This situation can be interpreted as that the use of MOX together with HCQ causes a synergistic effect on QT interval prolongation. However, no arrhythmia and arrhythmia related mortality was observed. Although there are no other studies conducted in terms of MOX use safety in COVID-19 patients, more studies on safe medication use in these patients are needed.

As the groups could not be randomized due to the retrospective nature of our study, it is seen that there is a significant age difference between the two groups. Although age was found to be an independent predictor for QT interval prolongation in previous studies, the cut-off value was reported as 68 years..$^{19}$ In our study, the median age was 42 years in the combination group and 39.5 years in the group that received HCQ alone. Consequently, although there is a significant age difference between the groups, considering the median ages, it will be seen that both groups are not in the age group which creates a risk in terms of QT prolongation.

There are many drugs that can cause QT interval prolongation. Although more QT interval prolongation is expected in patients who use more than one drug compared to those who use one drug, in a study, there was no difference in terms of QT prolongation among those who used one or more drugs that could prolong the QT interval. ${ }^{19}$ On the contrary, in another study, significant QT interval prolongation was not observed in patients using only an antipsychotic drug, while significant QT interval prolongation was found in those combined with antidepressants or lithium. ${ }^{20}$ In our study, a significantly higher QT interval prolongation was observed in the combination group of HCQ and MOX compared to the group that received only HCQ. With the use of two drugs together, more QT interval prolongation can be explained by two mechanisms. The first is due to the synergistic blockade effect of both drugs on Herg potassium channels, and the second is that the two drugs are metabolized in the same way and cause an increase in drug blood levels as a result of affecting each other's pharmacokinetics.

In the current study, we found out that when combined with $\mathrm{HCQ}, \mathrm{MOX}$ causes a significant decrease in heart rate. No data can be found suggesting that MOX alone causes bradycardia. In the pharmacological safety study of the medication, it was determined that it causes a prolonged QT, yet no change in heart rate or blood pressure. ${ }^{21}$ Also, it is revealed that MOX in a standard clinical dosage can cause a mild increase in the heart rate in some individuals which can be significant. ${ }^{22}$

When all the patients in the study are evaluated, QTC intervals of only five patients were found $500 \mathrm{~ms}$ and above. When these patients were monitored, no arrhythmic cases were observed in any of these patients. In the global scale, the lesser number of QTc $\geq 500 \mathrm{~ms}$ patients can be explained by a higher mean age in other similar studies. Also, when both the patient groups are considered, it is found out that seven (3.0\%) patients lost their lives, and none of the patients' cause of death was arrhythmia related. After discharge, all our patients were contacted via phone, and arrhythmic cases and mortality were asked. No cases were detected in any of the patients.

\section{Conclusions}

As researchers, we have determined that $\mathrm{HCQ}$, when used alone or with MOX used in COVID-19 treatment, causes a significant prolonging in QTc. Moreover, when it is combined with MOX, the prolonging in QTc interval is significantly higher when compared with $\mathrm{HCQ}$ alone. Despite the fact that they are used in a combination with HCQ, our data is the first study in the literature showing that when combined with MOX, there is a significant prolonging in QTc when compared with HCQ alone treatment. The clinically significant QTc prolonging (QTc $\geq 500 \mathrm{~ms}$ ) was observed in only five patients, and no arrhythmic cases and related cardiac mortality was found. We can explain our lower rates by considering that our patient group has a lower level of arrhythmic risk factor when compared to the other studies. In order to evaluate the effect of MOX on QT interval and arrhythmic cases, more studies are needed. In the light of our study data, it is concluded that the patients receiving $\mathrm{HCQ}$ and $\mathrm{HCQ}$ and 
MOX combination treatments should be observed in terms of bradycardia even though it is not symptomatic or needs intervention.

\section{Limitations}

As a retrospective study during an ongoing pandemic, this study has several limitations. The most important limitation of the study is that it is not randomized blinded. Larger, multicenter, prospective studies are required to confirm our preliminary findings. Since our study, population consists of only the non-ICU patients who are followed up in the ward. The QT interval prolonging and arrhythmic cases can be different from our findings in the patients who are in clinically severe condition.

\section{Conflict of interest}

None.

\section{Funding}

None.

\section{References}

1. Chen L, Liu W, Zhang Q, et al. RNA based mNGS approach identifies a novel human coronavirus from two individual pneumonia cases in 2019 Wuhan outbreak. Emerg Microbes Infect 2020;9:313-319.

2. Zhu N, Zhang D, Wang W, et al. A Novel Coronavirus from Patients with Pneumonia in China, 2019. N Engl J Med 2020;382:727-733.

3. Chen $\mathrm{CY}$, Wang FL, Lin CC. Chronic hydroxychloroquine use associated with QT prolongation and refractory ventricular arrhythmia. Clin Toxicol (Phila) 2006;44:173-175.

4. Soumya RS, Unni TG, Raghu KG. Impact of COVID-19 on the Cardiovascular System: A Review of Available Reports. Cardiovasc Drugs Ther 2021;35:411-425.

5. Garcia-Cremades $M$, Solans BP, Hughes $E$, et al. Optimizing Hydroxychloroquine Dosing for Patients With COVID-19: An Integrative Modeling Approach for Effective Drug Repurposing. Clin Pharmacol Ther 2020;108:253-263.

6. Briasoulis A, Agarwal V, Pierce WJ. QT prolongation and torsade de pointes induced by fluoroquinolones: infrequent side effects from commonly used medications. Cardiology 2011;120:103-110.

7. Ministry of Health (2019). Ulusal Pandemi Hazırlık Planı [online].Website: https://hsgm.saglik.gov.tr/tr/ bulasicihastaliklar-haberler/ulusal-pandemi-hazirlik-plani.html [accessed 17. April 2020]

8. Anderson ME, Al-Khatib SM, Roden DM, Califf RM. Cardiac repolarization: Current knowledge, critical gaps, and new approaches to drug development and patient management. Am Heart J 2002;144:769-781.

9. Clerkin KJ, Fried JA, Raikhelkar J, et al. COVID-19 and Cardiovascular Disease. Circulation 2020;141:1648-1655.

10. Chen Z, Hu J, Zhang Z, et al. Efficacy of hydroxychloroquine in patients with COVID-19: results of a randomized clinical trial. MedRxiv 2020:2020.03.22.20040758.

11. Mercuro NJ, Yen CF, Shim DJ, et al. Risk of QT Interval Prolongation Associated With Use of Hydroxychloroquine With or Without Concomitant Azithromycin Among Hospitalized Patients Testing Positive for Coronavirus Disease 2019 (COVID-19). JAMA Cardiology 2020;5:1036-1041.

12. Saleh M, Gabriels J, Chang D, et al. Effect of Chloroquine, Hydroxychloroquine, and Azithromycin on the Corrected QT Interval in Patients With SARS-CoV-2 Infection. Circ Arrhythm Electrophysiol 2020;13:e008662.

13. Capel RA, Herring N, Kalla M, et al. Hydroxychloroquine reduces heart rate by modulating the hyperpolarizationactivated current If: Novel electrophysiological insights and therapeutic potential. Heart Rhythm 2015;12:2186-2194.

14. Cairoli E, Danese N, Teliz M, et al. Cumulative dose of hydroxychloroquine is associated with a decrease of resting heart rate in patients with systemic lupus erythematosus: a pilot study. Lupus 2015;24:1204-1209.

15. Romani S, Gérard A, Fresse A, et al. Insights on the evidence of cardiotoxicity of hydroxychloroquine prior and during COVID-19 epidemic. Clin Transl Sci 2021;14:163-169.

16. Rubinstein E, Camm J. Cardiotoxicity of fluoroquinolones. J Antimicrob Chemother 2002;49:593-596.

17. Viskin S, Justo D, Halkin A, Zeltser D. Long QT syndrome caused by noncardiac drugs. Prog Cardiovasc Dis 2003;45:415-427.

18. Afsin A, Ecemis K, Asoglu R. Effects of Short-Term Hydroxychloroquine Plus Moxifloxacin Therapy on Corrected QT Interval and Tp-e Interval in Patients With COVID-19. J Clin Med Res 2020;12:604-611.

19. Tisdale JE, Jaynes HA, Kingery JR, et al. Development and validation of a risk score to predict QT interval prolongation in hospitalized patients. Circ Cardiovasc Qual Outcomes 2013;6:479-487.

20. Sala M, Vicentini A, Brambilla P, Montomoli C, Jogia JR, Caverzasi $\mathrm{E}$, et al. QT interval prolongation related to psychoactive drug treatment: a comparison of monotherapy versus polytherapy. Ann Gen Psychiatry 2005;4:1.

21. Kim EJ, Shin WH, Kim KS, Han SS. Safety pharmacology of DW224a, a novel fluoroquinolone antibiotic agent. Drug Chem Toxicol 2004;27:295-307.

22. Mason JW, Moon TE. Moxifloxacin Increases Heart Rate in Humans. Antibiotics (Basel, Switzerland) 2017;6:5. 